\title{
THE SEGREGATION OF WHITE AND COLORED PASSENGERS ON INTERSTATE·TRAINS
}

In the transportation of passengers common carriers are at liberty to establish rules and regulations for the accommodation of white and colored passengers. In some States where the colored population is large, public sentiment demands and requires a separation of the races, to prevent the breach of the peace. In order to obtain this security, State laws are enacted to require common carriers to provide separate accommodations, which statutes are enforceable so long as they are confined to intrastate commerce. Laws of this character are enacted and are binding upon the corporations engaged in intrastate commerce for the purpose of furthering the public health, the public morals, the public convenience and the public order under the terms of the police power of the State, because there is that natural distinction between passengers of race and color, which justifies their separation when passengers on public conveyances. This segregation has been the subject of sound legislation.

Few persons who inderstand the conditions can deny the danger to the peace engendered by the feeling of aversion between the individuals of the different races; although this impunity may not be absolute proof, nevertheless it is the feeling that prevails, and science teaches that it is much easier and more politic to avert serious consequences than afterwards to punish for the breach of the peace. This fact has been determined by numerous decisions. Wherever such statutes have been enacted by the States they have been held by the Supreme Court of the United States not to be irregular in requiring separate accommodations for white and colored passengers, nor in conflict with the provisions of the Thirteenth and Fourteenth Amendments of the Constitution of the United States.

This matter of discretion is given to the legislature, so that in determining the question of reasonableness it is at liberty to act with reference to the established usages and customs and traditions of the people with the intention to preserve the good order and the public peace. Upon this basis is gauged the standard for the separation of white and black passengers on intrastate trains, 
which does not involve the question of interstate commerce. The power to regulate interstate commerce is positively vested in Congress, but statutes enacted by the States not in conflict with this power are valicl. It seems to be a well settled principle of the law that common carriers have the right, when no statute intervenes, to establish such rules and regulations requiring colored passengers to occupy special coaches or compartments separate and distinct from those set apart for the white passengers. Under the powers of the States over the general stubject of commerce it was determined that States may establish such laws in the absence of legislation by Congress, which enactments may embrace the regulation of pilots, quarantine, inspection laws, policing of harbors and the regulation of wharves; also instances of requiring engineers to undergo an examination of the eyes for color blindness, or defective vision. and obtain a license from the State board before being permitted to run trains in the State. ${ }^{1}$ It is within the police power to prescribe that separate coaches shall be supplied by carriers within its border for colored passengers. Such State statutes have no application to interstate commerce but apply only within the borders of the State. They cannot be abrogated by a judgment of a Federal court, if it appears that the Supreme Court of the State has construed and declared that such enactments are only intencled for intrastate transportation. These enactments are not regulations of interference, althougli they control in some clegree the conduct and liability of those engaged in interstate commerce. and regulate the relative duties of persons and corporations within their limits. but are regardedaslegislation in aid of interstate commerce. In $M$. $K$. \& $T$. Ry. v. Habcr," the learned juclge saicl that "even if subject of State regulation be one that mar be taken under the exclusive control of Congress and be reached by national legislation, any action taken by the State upon this subject that does not directly interfere with rights secured by the Constitution of the United States, or by some valid act of Congress. must be respected until Congress intervenes." The State of Georgia forbade the running of freight trains on the railroarls in the State on Sunclay and declared a violation of the statute to be a misdemeanor, which enactment was intencled for trains transporting domestic freight within the State. It was not intended

\footnotetext{
${ }^{1} 154$ U. S. 204.
}

2 I69 U. S. $6 \mathrm{r} 3$. 
as an enactment to regulate interstate commerce, and while in a limited degree the statute may affect such commerce, it is not strictly a regulation of it. ${ }^{3}$ A State may regulate the speed of trains within city limits, and such act is, even as to interstate trains, one only indirectly affecting interstate commerce, and within the powers of the State, at least until Congress takes action in the mat-

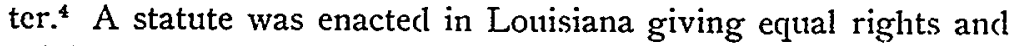
privileges to all persons traveling in vessels employed in the transportation of passengers in the State, without discrimination or distinction as to race or color, but the United States Supreme Court said that the "State legislature which seeks to impose a direct burden upon interstate commerce, or to interfere directly with its freedom does encroach upon the exclusive power of Congress," and that the statute occupied that position. Such a law must necessarily influence the conduct of the carrier throughout its entire business, while only purporting to control the carrier when engaged within the State. If each State could regulate the control of carriers while within its. jurisdiction, the confusion likely to follow could not be otherwise than productive of great inconvenience and unnecessary harlship."

In view of the fact that "Congress has not seen fit to prescribe any specific rules to govern interstate commerce, the inaction is equivalent to a declaration that interstate commerce shall be free and untrammelled."' Under the authorities we find that Congressional inaction leaves the carrier at liberty to adopt reasonable rules for the disposition of passengers. The statute of Louisiana, as construed by the State courts, seems to take from the carriers this power so long as they are within the State, and therefore it has been declared void and unconstitutional. The power of regulation may be exercised without legislation as well as with legislation. By "refraining from action, Congress, in effect, adopts as.its own regulations those which the common law, or the civil law, where that prevails, has provided for the government of such business, and those which the States, in the regulation of their domestic concerns, have established affecting commerce. If the public good requires such legislation, it must come from Congress and not from the States." "By many

\footnotetext{
${ }^{3}$ Hennington v. Ga., 163 U. S. 299

${ }^{4}$ Erb v. Morasch. I77 U. S. 584.

"Hall v. DeCuir, 95 U. S. 485.

${ }^{\circ} 9 \mathrm{I}$ U. S. 282.

T 95 U. S. 582.
} 
decisions it has been determined that States have no right to interfere in the matter of interstate commerce."s A statute of Mississippi, requiring all railroads carrying passengers in that State, except street railways, to provide equal but separate accommodations for the white and colored passengers, was held to be within the powers of the State, and not a regulation of interstate commerce, as the Supreme Court of that State declared that it applied only to commerce within its borders. ${ }^{\circ}$ Whether interstate passengers of one race should, in any portion of the journey, be compelled to share their cabin accommodations with passengers of another race was held to be a question of interstate commerce, which must be determined by Congress alone.

The broad question of the right under the Thirteenth and Fourteenth Amendments to the Constitution to segregate white and colored passengers has been upheld by the Supreme Court of the United States in the instance where a negro purchased a ticket and occupied a vacant seat in the coach where white passengers were accommodated, and was ejected under a separate coach law of the State of Louisiana. The validity of the statute was attacked on the ground that it abridged the privileges and immunities of citizens, denying them equal protection of the laws. ${ }^{10}$ In this case Justice Harlan dissented on the ground that the statute of Mississippi was, within the decision in Hall v. DeCuir, ${ }^{11}$ a regulation of commerce among the States and necessarily void. On the contrary it is declared that legislation which is merely an aid to intrastate commerce may be enacted by a State although at the same time it may indirectly affect interstate commerce itself.

The foregoing cases referred to, raise and dispose of the race question, if under an act its operation applies only to those passengers traveling from point to point within the State, or requires such passengers to be assigned to separate coaches when traveling from or to points in other States. Such a law would apply to intrastate passengers, but if an attempt should be made to apply it to interstate passengers the construction would undoubtedly be declared unconstitutional. A police regulation can-

\footnotetext{
${ }^{8}$ II8 U. S. 557.

${ }^{9}$ I33 U. S. 59I.

10 Plessy v. Ferguson, I63 U. S. 537.

1195 U. S. 485 .
} 
not be so extensive that it becomes national in character. The Supreme Court will not permit laws which in any way regulate interstate commerce. A State may make reasonable regulations to secure the safety of the passengers, even on interstate trains, while within its borders. But a State cannot enact any regulation which will directly burden or impede the interstate traffic of the carrier, or impair the usefulness of its facilities for such traffic. ${ }^{12}$ The failure of Congress to act as to matters of national character is, as a rule, equivalent to a declaration that they shall be free from regulation or restriction by any statutory enactment, and it is well settled that interstate commerce is national in character. Again, a statute that requires the separation of white and colored passengers and applies only so far as intrastate transportation extends is held valid so far as it affects commerce wholly within the State, but it is invalid as to interstate passengers under the commerce clause of the constitution and necessarily must be construed as not applying to them. ${ }^{13}$ The legislation would be an attempt to exercise a power to regulate commerce directly, but in case of conflict between the powers claimed by the States and those which belong exclusively to Congress, the former power must yield for the Constitution and the laws in pursuance thereof are the "supreme laws of the land."

Under the commerce act, carriers may place white and colored passengers in separate cars, but they cannot discriminate in the accommodations which they furnish to each, which must be substantially equal in quality and convenience. If it be deemed necessary for the comfort and safety of the passengers, and especially for the preservation of order by reason of numbers, or the feeling between the races is such as to make it desirable to keep them separated, the carriers thenselves have complete authority to establish and adopt such regulations on interstate commerce trains as would relieve them of all the danger and inconvenience that may arise on account of the two races traveling together. A colored passenger is denied the right of equal accommodation if he is unable to obtain a seat in the car set apart for colored passengers because the car is crowded and the seats are all occupied. ${ }^{14}$ A carrier of passengers by steamboat cannot rightfully exclude colored passengers from the regular table and require them to take a seat with the guards in the boat or in a pantry. "But a colored passenger on a steamboat, who refused to move from

\footnotetext{
12 I63 U. S. I42.

${ }^{13} 50$ Atl. 457.

${ }^{14} 67$ S. W. 1085.
} 
one table to another on being requested to do so, because of objections to his presence on the part of the white passengers, and whose supper is duly furnished him, cannot complain of discrimination because, upon his refusal to move, the white passengers are removed to another table, leaving him alone." ${ }^{1.5}$

A negro woman purchased a ticket and entered and occupied a seat in the car assigned to white passengers, whereupon she was informed and requested to go forward and occupy a portion of another car set apart for the people of her race. This she refused to do, so she was removed with only the necessary assistance required for the purpose. In this case the facts showed the undue and unjust discrimination in some particulars of accommodations against the colored passengers.

Carriers may not discriminate between white and colored passengers, paying the same fare, in the accommodations which they furnish for each. But when a carrier provides facilities for personal cleanliness in first-class coaches clevoted to the use of white passengers, and a smoking compartment for the use of such passengers, also similar accommodations should be provided for colored passengers paying the same first-class fare. ${ }^{13}$

Another complaint made before the Interstate Commerce Commission by a negro for discrimination upon an interstate train traveling from Atlanta, Ga., to Washington, D. C., charged that carriers did not provide accommodations for colored passengers equal to those furnished for white passengers. He purchased first-class tickets and the car occupied by himself and wife was a compartment car where smoking was permitted, which was not permitted in those occupied by the white passengers. The car in which he rode was partitioned, one portion being marked "colored," to be used by the negroes, and the other portion marked "white ;" also the toilet was in improper condition, being out of repair and broken, with no soap or towels, which condition was somewhat disputed by the carrier. A case of unjust discrimination was not made clear, and the Commission said that it was hardly within its power to order that the carrier must at its peril refrain from causing emergency conditions or that in the event that such a condition does obtain, a train must be delayed. The same equipment must be furnished both races whenever the carrier adopts rules for the separation

\footnotetext{
$1: 37$ Fed. Rep. 639.

30 I2 I. C. C. 284.
} 
of white and colored passengers, and a discrimination cannot be made.

People of color ride in Pullman sleeping cars, which car company does the best it can for their accommodation under the circumstances. If there is no available space no reservation can be obtained whether the passenger is white or colored. The right of a negro to obtain a berth in a Pullman car is not denied on interstate trains, if accommodations are available. The right of a carrier to separate passengers is founded upon two grounds-the public interest, and the right of private property in the resources of conveyance. The Pullman company is a common carrier and a colored passenger who has purchased a first-class ticket has a right as a matter of law, to obtain a seat in the Pullman car, provided such accommodations are furnished white passengers who purchase first-class tickets. Transportation companies may be subjected to public control in the interest of the public convenience and comfort, and if separate accommodations are generally demanded and not unreasonably burdensome, they may be compelled by law.

Social conditions which form a basis for discrimination are undoubtedly understood best by those persons living in the localities inhabited by a clense black population in Southern or Southwestern States. The people of the Eastern and Northern States are unaccustomed to the black element and in these sections of the country the color line is not closely drawn. In an instance of discrimination in Pennsylvania, a judge declared that it was near time that prejudice should be removed and social conditions be equal for transportation, but it may safely be said that he had little social relations with the colored race. Socially, the colored race is inferior to the white, but the law recognizes the colored man otherwise by numerous judicial decisions, or he would very soon lose his legal status.

We have seen that State statutes against the intermingling of white and colored passengers are valid in so far as they are construed and applied to intrastate transportation, but such statutes cannot interfere with interstate trains carrying passengers between interstate points. This separation can be accomplished by the carriers when they establish and adopt regulations necessary for the purpose of separation, which rules they are at liberty to enforce. Such regulations would be upheld as a special privilege of the carriers. A Federal statute is necessary to compel 
interstate carriers to separate colored and white passengers, and if such legislation could be accomplished the separation of the races in transportation would be a worthy regulation of commerce. In the absence of such Federal legislation, a similar regulation adopted by the carriers themselves would be most gratifying, and it would be regarded with favor not only by the white, but also by the colored race.

District of Columbia Bar.

J. Newton Baker. 